\title{
Correction to: When is an abscess more than an abscess? Syringe services programs and the harm reduction safety-net: a case report
}

Marcus Castillo ${ }^{1}$, Margaret E. C. Ginoza ${ }^{1}$, Tyler S. Bartholomew², David W. Forrest ${ }^{3}$, Costaki Greven ${ }^{4}$, David P. Serota ${ }^{5}$ and Hansel E. Tookes ${ }^{5}$

\section{Correction to: Harm Reduction Journal (2020) 17:34}

https://doi.org/10.1186/s12954-020-00381-4

After publication of the original article [1], the authors identified an error in the author name of Costaki Greven.

The incorrect author name is: Cestaki Greven

The correct author name is: Costaki Greven

The author group has been updated above and the original article [1] has been corrected.

\begin{abstract}
Author details
${ }^{1}$ Department of Medical Education, University of Miami Miller School of Medicine, Miami, FL, USA. ${ }^{2}$ Department of Public Health Sciences, University of Miami Miller School of Medicine, 1120 NW 14th St, Miami, FL 33136, USA. ${ }^{3}$ Department of Anthropology, College of Arts and Sciences, University of Miami, Miami, FL, USA. ${ }^{4}$ IDEA Exchange, University of Miami Miller School of Medicine, Miami, FL, USA. ${ }^{5}$ Division of Infectious Diseases, Department of Medicine, University of Miami Miller School of Medicine, Miami, FL, USA.
\end{abstract}

Published online: 24 June 2020

\section{Reference}

1. Castillo, et al. Harm Reduction J. 2020;17:34 https://doi.org/10.1186/s12954020-00381-4.

The original article can be found online at https://doi.org/10.1186/s12954020-00381-4

* Correspondence: Tsb61@miami.edu

${ }^{2}$ Department of Public Health Sciences, University of Miami Miller School of Medicine, 1120 NW 14th St, Miami, FL 33136, USA

Full list of author information is available at the end of the article

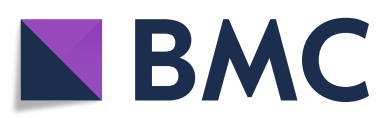

(- The Author(s). 2020 Open Access This article is licensed under a Creative Commons Attribution 4.0 International License, which permits use, sharing, adaptation, distribution and reproduction in any medium or format, as long as you give appropriate credit to the original author(s) and the source, provide a link to the Creative Commons licence, and indicate if changes were made. The images or other third party material in this article are included in the article's Creative Commons licence, unless indicated otherwise in a credit line to the material. If material is not included in the article's Creative Commons licence and your intended use is not permitted by statutory regulation or exceeds the permitted use, you will need to obtain permission directly from the copyright holder. To view a copy of this licence, visit http://creativecommons.org/licenses/by/4.0/ The Creative Commons Public Domain Dedication waiver (http://creativecommons.org/publicdomain/zero/1.0/) applies to the data made available in this article, unless otherwise stated in a credit line to the data. 